\title{
Peran Dinas Kelautan dan Perikanan Kabupaten Kepulauan Anambas dalam Perlindungan Ikan Napoleon (Studi di Desa Air Sena Kecamatan Siantan Tengah)
}

\author{
Billy Jenawi ${ }^{1}$, Ferizone ${ }^{2}$, Ana Jemi ${ }^{3}$ \\ ${ }^{I}$ STISIPOL Raja Haji Tanjungpinang \\ ${ }^{2}$ STISIPOL Raja Haji Tanjungpinang \\ ${ }^{3}$ STISIPOL Raja Haji Tanjungpinang
}

\section{INFORMASI ARTIKEL}

Sejarah Artikel:

Diterima Redaksi: 20 Juli 2019

Revisi Akhir: 1 Agustus 2019

Diterbitkan Online: 30 Agustus 2019

\section{KATA KUNCI}

Peran, Ikan Napoleon, Kepulauan Anambas

\section{KORESPONDENSI}

No HP: 082288429691

E-mail: billyjenawi08@gmail.com

\begin{abstract}
A B S T R A C T
Napoleon fish is one of the types of fish that have a high economic value. Kepulauan Anambas is one of the regions in Indonesia which has a population of Napoleon fish the most. To protect the fish from extinction Government was published a decision of the Minister of Marine and Fisheries the number 37 Year 2013 regarding the determination of the Status of the protection of Napoleon. To view the roles carried out by the Department of Marine and Fisheries Kepulauan Anambas used theory of the role from Siagian with the indicator stabilizer, innovators, modernisator, pioneer and implementors. Type of research is qualitative with descriptive analysis techniques. The results of this research show that the role of the Department of Marine and Fisheries was keep order fishers in the protection of Napoleon fish by making policies to maintain fisherman economic stability and fishermen by creating joint ventures. Role as innovator, Department of marine and Fisheries have made special location fish protection Napoleon and applied cultivation grouper so not just farmed fish of Napoleon. As modernisator the Marine and Fisheries Agency has not used a technology that could help in the Napoleon fish farming but the Office of maritime and Fishery will make Napoloen fish as one of the tourist attractions. His role as a pioneer, Marine and Fisheries Agency has delivered fishing aspirations and also increase public awareness through socialization. As executor, Department of marine and Fisheries surveillance has been instrumental in the capture and exportation
\end{abstract}

\section{PENDAHULUAN}

Indonesia merupakan negara maritim terbesar di dunia, dimana luas wilayahnya terdiri dari $30 \%$ daratan dan sisanya sebesar $70 \%$ merupakan lautan. Sebagai negara yang memiliki banyak sekali pulau, maka lautan dianggap sebagai suatu sarana penghubung antar wilayah. Wilayah lautan yang luas, tentu saja memiliki dampak positif dengan melimpahnya sumber daya laut yang terkandung di dalamnya untuk dapat dimanfaatkan bagi masyarakat.

Namun, potensi kekayaan yang ada dapat menimbulkan bencana apabila dalam pengelolaannya tanpa memperhatikan norma, kaidah serta batas kemampun alam. Dampak yang cukup dirasakan dari kegiatan pengelolan tersebut adalah pengaruhnya terhadap ekosistem lingkungan laut, terutama pengelolaannya tanpa memeperhatikan ketentuan dan persyaratan yang telah diatur oleh Pemerintah.

Salah jenis sumber daya kelautan yang dimiliki oleh Indonesia adalah ikan. Banyak sekali jenis ikan di wilayah perairan Indonesia bahkan ada beberapa jenis yang sudah dapat dikategorikan sebagai ikan langka dan terancam punah. Salah satu penyebabnya adalah pemanfaatan yang berlebihan tanpa memperhatikan keberlanjutan dari keberadaan ikan di wilayah perairan Indonesia, ini mengambarkan bahwa banyak pihak baik pemerintah maupun masyarakat luas belum menyadari nilai penting dari pelestarian sumber daya kelautan tersebut bagi kelangsungan dan kesejahteraan hidup masyarakat.

Salah satu jenis ikan yang dilindungi oleh Pemerintah Indonesia ialah Ikan Napoleon atau dalam bahasa latin disebut Cheilinus Undulates. Ikan ini dikenal sebagai salah satu komoditas unggulan yang memiliki nilai ekonomis tinggi. Sejak tahun 1990, permintaan terhadap ikan Napoleon sangat tinggi 
sehingga kegiatan penangkapan ikan ini dilakukan secara masif. Penangkapan ikan ini dilakukan dengan alat tangkap yang bersifat legal (jaring insang, pancing dan bubu) maupun ilegal (racun sianida dengan alat bantu kompresor). Sebagai akibatnya, populasi ikan jenis tersebut mengalami penurunan yang sangat signifikan sehingga menetapkan bahwa ikan Napoleon merupakan salah satu ikan yang dilindungi di dunia karena dianggap telah langka dan terancam populasinya di alam.

Pada perdagangan internasional, jual beli ikan ini sudah dilakukan sejak lama karena menjadi salah satu sumber pendapatan yang begitu besar. Hal ini disebabkan tingginya harga ikan Napoleon di pasaran internasional. Oleh sebab itu, eksploitasi terhadap spesies ikan tersebut marak sekali terjadi.

Pada Pedoman Survei Populasi ikan Napoleon, penelitian yang dilakukan oleh (Edrus dkk, 2012:13) menyebutkan "pada tahun 2003-2010 di 9 Provinsi, yaitu di Kepulaua Riau (Kepulauan Natuna), Sumatera Barat (Kepulauan Mentawai), Bangka Belitung (Pulau Belitung), Jawa Tengah (Kepulauan Karimun Jawa), Sulawesi Selatan (Pulau Sembilan-Sinjai), Sulawesi Tenggara (Kepulauan Wakatobi), Sulawesi Tengah (Kepulauan Banggai), Kalimantan Timur (Kepulauan Derawan) dan Nusa Tenggara Timur (Pulau Komodo dan sekitarnya) menyatakan bahwa populasi ikan Napoleon turun drastis".

Tingginya harga dan ekslpoitasi terhadap ikan Napoleon dapat menyebabkan berkurangnya populasi ikan ini secara masif. Dalam rangka penyelamatan sumberdaya alam laut dari ancaman kepunahan akibat penangkapan lebih di alam (overfishing) diperlukan upaya konservasi. Tujuan utama kegiatan konservasi adalah perlindungan terhadap spesies yang terancam punah dan keberlanjutan pemanfaatan beberapa spesies yang mempunyai nilai ekonomi, disamping tujuan lain yang tidak kalah pentingnya seperti memelihara kualitas lingkungan atau ekosistem yang tetap baik dan lestari. Hal itu dikarenakan ikan Napoleon merupakan golongan ikan yang hidup di perairan karang (terumbu karang).

Jenis ikan Napoleon merupakan ikan terbesar dari kelompok Labridae, dapat mencapai ukuran 2 (dua) meter dengan berat $190 \mathrm{~kg}$. Pada terumbu karang dengan tekanan penangkapan relatif rendah, ukuran ikan Napoleon ditemukan bervariasi dengan panjang antara $60-100 \mathrm{~cm}$. Ukuran panjang ikan Napoleon mempunyai korelasi dengan ukuran berat, ikan Napoleon dengan berat 1000 gram mempunyai panjang $\pm 38 \mathrm{~cm}$ dan ikan Napoleon yang mempunyai berat sekitar 3000 gram mempunyai panjang $\pm 55 \mathrm{~cm}$.

Ikan Napoleon memiliki pola produksi Protogynus Hermaphrodite, dimana yang lahir sebagai betina akan berubah kelamin menjadi jantan pada saat mengijak dewasa ukuran 55

Billy Jenawi cm dan $75 \mathrm{~cm}$. Ikan Napoleon cendrung hidup soliter, berpasangan, atau sering dijumpai dalam kelompok kecil antara 3 sampai dengan 7 ekor. (Keputusan Menteri Kelautan dan Perikanan Nomor 37 Tahun 2013 tentang tentang Penetapan Status Perlindungan Terbatas Ikan Napoleon (Cheilinus Undulatus)).

Ikan Napoleon memiliki rata-rata penambahan populasi yang rendah, hal tersebut disebabkan pertumbuhannya yang lambat, umur yang panjang dan keterlambatan reproduksi. Hanya sedikit penelitian yang menyediakan informasi biologi tentang ikan Napoleon, karena kepadatan populasinya saat ini rendah di alam dan kelimpahannya semakin sedikit di wilayah penangkapan. Selain itu Ikan napoleon bersifat hermaprodit protogini dan mencapai kematangan seksual pada umur 5-7 tahun (Syam dkk, 2016:184). Penurunan populasi ikan Napoleon terjadi sejak tahun 1990-an, permintaan dunia akan ikan Napoleon meningkat drastis dengan harga jauh di atas ikan karang lainnya.

Berkurangnya jumlah populasi ikan Napoleon di beberapa daerah di Indonesia dan dengan harga jual yang tinggi menyebabkan ikan Napoleon masuk dalam kategori rawan punah dan masuk dalam Appendiks II CITES tahun 2004 (http://bpsplpadang.kkp.go.id/status-perlindungan-napoleon diakses 4 April 2018).

Meskipun demikian perdagangan secara terbatas masih diperbolehkan dengan penerapan sistem kuota yang membatasi jumlah ikan yang boleh diekspor per tahun dan pintu ekspor ke luar negeri, (Syam dkk, 2016:148).

Dalam menyikapi perkembangan terbaru dalam status perikanan dan pemanfaatan ikan Napoleon, pemerintah merasa perlu melakukan insiatif perlindungan terhadap ikan Napoleon. Pemerintah mengambil kebijakan dengan mengeluarkan Peraturan Menteri Kelautan dan Perikanan Nomor PER.03/MEN/2010 tentang Tata Cara Penetapan Status Perlindungan Jenis Ikan.

Peraturan ini menjadi pintu masuk bagi penetapan regulasi perlindungan terbaru ikan Napoleon. Atas dasar inisiatif tersebut, Kementrian Kelautan dan Perikanan mengeluarkan Keputusan Menteri Kelautan dan Perikanan Nomor 37 Tahun 2013 tentang tentang tentang Penetapan Status Perlindungan Terbatas Ikan Napoleon (Cheilinus Undulatus). Dengan ditetapkannya Keputusan Menteri tersebut tersebut, maka Keputusan Menteri Pertanian Nomor 375/Kpts/IK.250/5/95 Tentang Larangan Penangkapan Ikan Napoleon Wrasse (Cheilinus Undulatus) dinyatakan tidak berlaku lagi.

Di dalam Keputusan Menteri Kelautan dan Perikanan Nomor 37 Tahun 2013 tentang Penetapan Status Perlindungan 
Ikan Napoleon (Cheilinus Undulatus). Status Perlindungan jenis ikan ada dua. Pertama adalah dilindungi penuh artinya ukuran, kapanpun, dan dimanapun di negara indonesia jenis ikan itu tidak boleh ditangkap dan diperdagangkan; sedangkan yang kedua, adalah dilindungi terbatas, terbatas menurut waktu, ukuran, atau tempat. Dengan diberikannya status dilindungi secara terbatas artinya masih diberikan peluang untuk pemanfaatanya. Terbatas menurut ukuran. Ukuran ikan napoleon yang dilindungi adalah 100 gr sd 1000 gr dan $>3000$ gr, ukuran itu yang dilindungi karena ukuran sd 100 gr diperuntukan untuk benih yang akan dipelihara di keramba. Ukuran <1000 gr baru pertama kali memijah, ukuran 1000 gr sd 3000 gr diperkirakan sudah beberapa kali memijah, dan ukuran $>3000$ gr adalah ukuran dimana terjadi perubahan kelamin dari betina ke jantan dan ukuran untuk indukan.

Ikan Napoleon bisa ditemukan di perairan karang Indonesia, salah satu wilayah di Indonesia yang memiliki potensi ikan Napoleon adalah di Kepulauan Anambas. Luas wilayah Kabupaten Kepulauan Anambas 98,65\% merupakan wilayah lautan sehingga kondisi ini sangat mendukung bagi pengembangan usaha perikanan, baik perikanan tangkap maupun budidaya perikanan.

Sektor perikanan tangkap merupakan salah satu sektor ekonomi yang berperan penting dalam perekonomian di Indonesia. Selain menjadi sumber pendapatan penduduk, sektor perikanan tangkap menjadi andalan bagi masyarakat pesisir sebagai sumber mata pencaharian (Asiati, 2016:108). Sementara di Kabupaten Anambas ini sendiri para nelayan tradisonal menjadikan ikan Napoleon sebagai target utama penangkapan. Pemanfaatan sumberdaya ikan Napoleon yang dilakukan oleh masyarakat nelayan di Kepulauan Anambas harus mengacu kepada beberapa kebijakan pemerintah yang mengatur tentang tata cara pemanfaatan ikan ini. Kebijakan ini berimbas pada adanya pembatasan ruang gerak dalam pemanfaatan yang dilakukan.

Di Indonesia, persebaran ikan Napoleon terdapat di beberapa daerah di Indonesia, salah satunya adalah Kabupaten Kepulauan Anambas. Ikan Napoleon merupakan jenis ikan primadona bagi nelayan dan pembudidaya di Kabupaten Kepulauan Anambas karena memiliki nilai ekonomi tinggi. Berikut ini adalah data jumlah pembudidaya dan jumlah ikan Napoleon tahun 2015-2016 berdasarkan desa-desa yang ada di Kabupaten Kepulauan Anambas:

Tabel 1

Pembudidaya dan Jumlah Ikan Napoleon

\begin{tabular}{|c|c|c|c|c|}
\hline $\mathbf{N}$ & KECAMATA & DES & PEMBUDIDAY & IKAN \\
$\mathbf{O}$ & $\mathbf{N}$ & $\mathbf{A}$ & $\mathbf{A}$ & NAPOLEO \\
& & & $\mathbf{N}$ \\
\hline
\end{tabular}

22 Billy Jenawi

\begin{tabular}{|r|l|r|r|r|}
\hline 1 & Siantan Tengah & 6 & 148 & 115.456 \\
\hline 2 & Palmatak & 11 & 154 & 19.418 \\
\hline 3 & Siantan Timur & 6 & 76 & 8.992 \\
\hline 4 & Jemaja Timur & 3 & 15 & 1.870 \\
\hline 5 & Jemaja & 2 & 2 & 155 \\
\hline 6 & Siantan Selatan & 2 & 2 & 66 \\
\hline \multicolumn{2}{r}{ Jumlah } & 30 & 397 & 145.957 \\
\hline
\end{tabular}

Sumber: Dinas Kelautan dan Perikanan (DKP) Kabupaten Kepulauan Anambas

Kegiatan penangkapan dan budidaya ikan Napoleon di Kepulauan Anambas salah satunya terfokus di Desa Air Sena Kecamatan Siantan Tengah. Dimana, di desa ini terdapat nelayan yang berjumlah 179 orang yang kebanyakan memang khusus menacari ikan Napoleon. Nelayan desa Air Sena pada umumnya lebih memilih pembesaran ikan sebagai sektor utama dalam melakukan aktivitas perekonomian. Selain itu, desa Air Sena menjadi salah satu daerah pengekspor ikan Napoleon, khususnya ke Hongkong yang menjadi pasar tunggal ikan Napoleon dari Anambas dan menjadi negara tujuan utama ekspor ikan ini dari Indonesia. Masyarakat nelayan desa Air Sena sampai sekarang masih melalukan pengakapan/budidaya ikan Napoleon sebagai mata pencaharian untuk kebutuhan hidupnya. Dapat dilihat data jumlah Napoleon yang dibudidayakan/dibesarkan di kerambah Desa Air Sena Tahun 2015.

Tabel 2

Data Jumlah Ikan Napoleon Yang Dibudidayakan/Dibesarkan Di Kerambah Di Desa Air Sena Kecamatan Siantan Tengah Kabupaten Kepulauan Anambas 2015

\begin{tabular}{|c|c|c|c|c|}
\hline $\begin{array}{c}\text { Jumlah } \\
\text { Budidaya }\end{array}$ & $\begin{array}{c}\text { Masa } \\
\text { pebesaran } \\
<2 \mathrm{TH}\end{array}$ & $\begin{array}{c}\text { Masa } \\
\text { pembesaran } \\
\mathbf{2} \text { s.d 4TH }\end{array}$ & $\begin{array}{c}\text { Masa } \\
\text { pembesar } \\
\text { an } \\
\mathbf{4} \text { TH }\end{array}$ & $\begin{array}{c}\text { Jumlah } \\
\text { (Ekor) }\end{array}$ \\
\hline 102 & 35,850 & 36,428 & 35,870 & 108,148 \\
\hline
\end{tabular}

Sumber: Dinas Kelautan dan Perikanan (DKP) Kabupaten Kepulauan Anambas

Tabel diatas menunjukkan bahwa terdapat nelayan yang berjumlah 102 orang melakukan budidaya ikan Napoleon di dalam kerambah nelayan, kegiatan ini diperlukan untuk menjaga populasi pada ikan Napoleon apabila penangkapan yang tidak terbatas pada Napoleon lama-kelamaan akan mengakibatkan kepunahan. Sedangkan perdagangan ikan Napoleon sudah berlangsung sejak lama dan merupakan komoditas unggulan dalam ekspor perikanan asal Indonesia.

Aktivitas penangkapan ikan di desa Air Sena menggunakan armada dan alat tangkap yang sederhana. Armada penangkapan nelayan biasanya disebut "pompong" menggunakan perahu kayu/papan dengan ukuran kecil, baik menggunakan mesin/motor maupun tanpa mesin. Nelayan desa Air Sena masih menggunakan teknologi penangkapan ikan secara tradisional dan sederhanan, yakni menggunakan alat 
tangkap pancing ulur, pancing tonda, rawai, jaring insang, jaring angkat, bubu dan perangkap lainnya.

Maka dari itu pemberian otonomi yang luas memberikan kesempatan bagi Pemerintah Daerah untuk meningkatkan daya saing dengan memperhatikan prinsip demokrasi, pemerataan keadilan, keistimewahan, dan kekhususan potensi dan keanekaragaman yang dimiliki oleh daerah. Undang-Undang Republik Indonesia Nomor 23 Tahun 2014 Tentang Pemerintah Daerah, telah memberi kewenangan bagi Pemerintah Daerah untuk mengelola dan mengkoordinasikan pemanfaatan sumberdaya yang ada dibidang kelautan dan perikanan.

Berdasarkaan Undang-Undang Nomor 31 Tahun 2004 tentang Perikanan sebagaimana telah diubah dengan UndangUndang 45 Tahun 2009, disebutkan bahwa perikanan adalah semua kegiatan yang berhubungan dengan pengelolaan dan pemanfaatan sumber daya ikan dan lingkungannya mulai dari praproduksi, produksi, pengolahan sampai dengan pemasaaran, yang dilaksanakan dalam suatu sistem bisnis perikanan. Pengelolaan usaha perikanan sangat beragam, mulai dari usaha menangkap ikan dan membudidayakan ikan.

Daerah yang memiliki wilayah laut diharapkan mampu memanfaatkan sumber daya yang ada khususnya sumber daya perikanan untuk digunakan kesejahteraan masyarakat yang ada di daerah terlebih bagi masyarakat nelayan. Pemanfaatan sumber daya perikanan ini merupakan upaya untuk mengembangkan potensi yang ada serta meningkatkan kesejahteraan masyarakat lewat hasil laut perikanan. Hal ini memberikan gambaran bahwa pengelolaan perikanan pada hakikatnya merupakan suatu kegiatan yang diharapkan mampu meningkatkan harkat dan martabat para nelayan yang berada di sekitar wilayah pesisir yang menggantungkan pendapatannya pada sektor perikanan dan merupakan penjabaran dari pembangunan perikanan secara berkelanjutan.

Pemanfaatan sumber daya perikanan harus mampu mewujudkan keadilan dan pemerataan, sekaligus memperbaiki kehidupan masyarakat nelayan. Perikanan merupakan sumber daya yang dapat pulih, dan dapat dimanfaatkan secara berkelanjutan jika dikelola dengan baik dan memperhatikan ikan-ikan yang dilindungi atau terancam punah sehingga tetap lestari dan terjaga. Dalam Peraturan Daerah Kabupaten Kepulauan Anambas Nomor 6 Tahun 2011 Pasal 77 Dinas Kelautan dan Perikanan mempunyai tugas melaksanakan urusan pemerintahan daerah berdasarkan asas otonomi dan tugas pembantuan dibidang kelautan dan perikanan serta tugas lain yang diberikan oleh Bupati. Selanjutnya dalam pasal 1 angka 7 disebutkan bahwa pengelolaan perikanan adalah semua upaya, termasuk proses yang terintegrasi dalam pengumpulan informasi, analisis, perencanaan, konsultasi, pembuat keputusan, alokasi sumberdaya ikan, dan implementasi serta penegak hukum dari peraturan perundang-undangan di bidang perikanan, yang dilakukan oleh pemerintah atau otoritas lain yang diarahkan untuk mencapai kelangsungan produktivitas sumberdaya hayati perairan dan tujuan yang telah disepakati.

Berdasarkan pengertian tersebut, maka pengelolaan perikanan merupakan aspek yang sangat penting untuk mengupayakan agar sumberdaya ikan dapat dimanfaatkan secara berkelanjutan. Peran pengelolaan sumber daya kelautan dan perikanan di pada tingkat daerah di Indonesia menjadi tanggungjawab Dinas Kelautan dan Perikanan. Peran tersebut dapat dilakukan melalui pengawasan, sosialisasi kepada masyarakat, dan menjalankan kebijakan.

Sebagian besar masyarakat di desa Air Sena menggantungkan hidup dari pemanfaatan sumberdaya yang ada khususnya menangkap ikan Napoleon. Sebagian besar masyarakat di desa Air Sena mata pencarian sebagai nelayan. Hal ini didukung dengan kondisi wilayah sebagai daerah kepulauan yang memiliki potensi kelautan dan perikanan yang sangat melimpah. Pontensi yang melimpah tanpa dibarengi dengan pengelolaan yang baik, tentunya sumberdaya tersebut tidak akan memberikan manfaat yang besar kepada masyarakat.

Penelitian ini bertujuan untuk menganalisis peran Dinas Kelautan dan Perikanan Kabupaten Kepulauan Anambas dalam perlindungan ikan Napoleon (Studi di Desa Air Sena Kecamatan Siantan Tengah).

\section{TINJAUAN PUSTAKA \\ Peran}

Biddle dalam Suhardono (2016:14) berpendapat bahwa konsep peran selalu dikaitkan dengan posisi. Posisi pada dasarnya adalah suatu unit dari struktur sosial. Ini berarti peran seseorang bergantung pada dimana posisi dia berada. Semakin Sedangkan menurut Riyadi (2002:138) Peran dapat diartikan sebagai orientasi dan konsep dari bagian yang dimainkan oleh suatu pihak dalam oposisi sosial. Dengan peran tersebut, sang pelaku baik itu individu maupun organisasi akan berperilaku sesuai harapan orang atau lingkungannya.

\section{Peran Pemerintah}

Siagian (2000:133) memaparkan bahwa terdapat lima fungsi utama pemerintah, antara lain:

a. Sebagai penyedia layanan, yaitu fungsi-fungsi pemerintah yang berkaitan dengan penyediaan pelayanan yang berorientasi pada lingkungan dan masyarakatnya. 
b. Fungsi pengaturan, yaitu fungsi yang berkaitan dengan perumusan dan penegakkan peraturan-peraturan.

c. Fungsi pembangunan yaitu fungsi yang berkaitan dengan keterlibatan pemerintah dalam kegiatan ekonomi.

d. Fungsi perwakilan yaitu mewakili masyarakat di luar wilayah mereka.

e. Fungsi koordinasi yaitu berkaitan dengan peran pemerintah dalam pengkoordinasiaan, perencanaan, investasi dan tata guna lahan.

Secara lebih jelas dan detail, peran pemerintah dalam pembangunan nasional dikemukakan oleh Siagian (2000:142150) yaitu pemerintah memainkan peranan yang dominan dalam proses pembangunan. Peran yang disoroti adalah sebagai stabilisator, inovator, modernisator, pelopor dan pelaksana sendiri kegiatan pembangunan tertentu. Secara lebih rinci peran tersebut diuraikan sebagai berikut:

\section{Stabilisator}

Peran pemerintah adalah mewujudkan perubahan tidak berubah menjadi suatu gejolak sosial, apa lagi yang dapat menjadi ancaman bagi keutuhan nasional serta kesatuan dan persatuan bangsa. Peran tersebut dapat terwujud dengan menggunakan berbagai cara antara lain. Kemampuan selektif yang tinggi, proses sosialisasi yang elegan tetapi efektif, melalui pendidikan, pendekatan yang persuasif dan pendekatan yang bertahap tetapi berkesinambungan.

\section{Inovator}

Merupakan salah satu produk dari kreativitas. Ditinjau dari segi administrasi pembangunan, inovasi berarti temuan baru, metode baru, sistem baru, dan yang terpenting, cara berfikir baru. Dengan demikian, dalam memainkan peran selaku inovator, pemerintah sebagai keseluruhan harus menjadi sumber dari hal-hal baru yang dikemukakan di atas. Jadi prakondisi yang harus terpenuhi agar efektif memainkan peranannya pemerintah perlu memiliki tingkat keabsahan (legitimacy) yang tinggi. Suatu pemerintahan yang tingkat keabsahannya rendah, misalnya karena "menang" dalam perebutan kekuasaan atau karena melalui pemilihan umum yang tidak jujur dan tidak adil, akan sulit menyodorkan inovasinya kepada masyarakat. Tiga hal yang mutlak mendapatkan perhatian serius adalah, penerapan inovasi dilakukan dilingkungan birokrasi terlebih dahulu, inovasi yang sifatnya konsepsional, inovasi sistem, prosedur dan metode kerja.

\section{Modernisator}

Melalui pembangunan, setiap negara ingin menjadi negara yang kuat, mandiri, diperlakukan sederajat oleh negara-negara lain. Untuk mewujudkan hal tersebut, diperlukan antara lain: penguasan ilmu pengetahuan, kemampuan dan kemahiran manajerial, kemampuan mengolah kekayaan alam yang dimiliki sehingga memiliki nilai tambah yang tinggi, sistem pendidikan nasional yang handal yang menghasilkan sumber daya manusia yang produktif, landasan kehidupan politik yang kukuh dan demokratis, memiliki visi yang jelas tentang masa depan yang diinginkan sehingga berorientasi pada masa depan.

4. Pelopor

Selaku pelopor pemerintah harus menjadi panutan (role model) bagi seluruh masyarakat. Pelopor dalam bentuk halhal, positif seperti kepeloporan dalam bekerja seproduktif mungkin, kepeloporan dalam menegakkan keadilan dan kedisiplinan, kepeloporan dalam kepedulian terhadap lingkungan, budaya dan sosial, dan kepeloporan dalam berkorban demi kepentingan negara.

\section{Pelaksana sendiri}

Meskipun benar bahwa pelaksanaan berbagai kegiatan pembangunan merupakan tanggung jawab nasional dan bukan menjadi beban pemerintah semata, karena berbagai pertimbangan seperti keselamatan negara, modal terbatas, kemampuan yang belum memadai, karena tidak diminati oleh masyarakat dan karena secara konstitusional merupakan tugas pemerintah, sangat mungkin terdapat berbagai kegiatan yang tidak bisa diserahkan kepada pihak swasta melainkan harus dilaksanakan sendiri oleh pemerintah.

\section{Peraturan Perlindungan Ikan Napoleon}

Ikan Napoleon atau dalam bahasa latin disebut dengan Cheilinus Undulatus merupakan komoditi yang memiliki nilai jual yang cukup tinggi, sehingga tidak mengherankan apabila jenis ikan ini menjadi incaran banyak pihak. (Edrus \& Suman 2014). Akibat dari perburuan yang dilakukan secara terus menerus menyebabkan populasi ikan ini semakin lama semakin memperihatinkan dan perlu dilakukan perlindungan.

Perlindungan terhadap populasi ikan Napoleon telah dilakukan sejak lama oleh pemerintah dengan dikeluarkannya beberapa peraturan antara lain: Peraturan Pemerintah Nomor 9 tahun 1985 dan Nomor 375/Kpts/IK.250/5/95 tentang Larangan Penangkapan Ikan Napoleon Wrasse (Cheilinus Undulatus); Keputusan Nomor: 95/EP/V/95 tanggal 21 Mei 1995 yang berisitentang larangan ekspor ikan Napoleon, kecuali atas izin Menteri Pertanian; Deklarasi Dirjen Perikanan No. HK.330/S3.6631/96 mengenai perubahan keputusan Dirjen Perikanan No. HK.330/Dj.8259/95 tentang ukuran, lokasi dan 
tata cara penangkapan ikan Napoleon; serta Peraturan Menteri Kelautan dan Perikanan Nomor PER.03/MEN/2010 tentang tata cara penetapan status perlindungan jenis ikan (Edrus 2011).

\section{METODOLOGI}

Penelitian ini merupakan jenis penelitian deskriptif dengan pendekatan kualitatif yang bertujuan untuk melihat bagaimana peran Dinas Keluatan dan Perikanan Kabupaten Kepulauan Anambas dalam perlindungan ikan Napaoleon khususnya di Desa Air Sena Kecamatan Siantan Tengah. Jenis penelitian ini dipilih karena penulis ingin mengeksplor fenomena-fenomena sosial yang bersifat deskriptif.

Sumber data yang digunakan dalam penelitian ini adalah: 1) data primer yang diambil dari sumber pertama di lapangan, diperoleh melalui hasil wawancara dengan para informan yang bersangkutan di tempat penelitian dari hasil wawancara yang dilakukan dengan para pihak yang mengetahui tentang peran Dinas Kelautan dan Perikanan Kabaupten Kepulauan Anambas dalam perlindungan ikan Napoloen terutama di Studi di Desa Air Sena Kecamatan Siantan Tengah; 2) data sekunder peneliti mengambil data dari berbagai sumber, baik dari buku, jurnal, berita, dokumen-dokumen dari institusi atau organisasi yang berhubungan dengan penelitian.

\section{HASIL DAN PEMBAHASAN}

Dinas Kelautan dan Perikanan Kabupaten Kepulauan Anambas sebagai organisasi perangkat daerah di Lingkungan Pemerintah Kabupaten Kepulauan Anambas, dalam keberhasilan pencapaian tujuan dan sasarannya sangat dipengaruhi oleh tingkat partisipasi dari seluruh pelaku pembangunan, sehingga Dinas Kelautan dan Perikanan dituntut untuk mampu memecahkan berbagai permasalahan dan tantangan di Kabupaten Kepulauan Anambas, dalam melayani atau memenuhi kebutuhan masyarakat serta memajukan daerah melalui pembangunan dalam sektor kelautan dan perikanan.

Sejalan dengan itu Peran Dinas Kelautan dan Perikanan Kabupaten Kepulauan Anambas berperan terhadap perlindungan ikan Napoleon di Desa Air Sena Kecamatan Siantan Tengah. Dimana ikan Napoleon merupakan ikan yang dilindungi dan terancam punah apabila tidak dijaga dengan baik dengan dikeluarkannya Keputusan Menteri Kelautan dan Perikanan Nomor 37 Tahun 2013 Tentang Status Perlindungan Ikan

\section{Peran Selaku Stabilisator}

Salah peran penting yang harus dijalani oleh Dinas Kelautan dan Perikanan Kabupaten adalah sebagai stabilisator yaitu menciptakan suasana yang stabil, sehingga pelaksanaan pembangunan di bidang Kelautan dan Perikanan bejalan efektif dan lancar tanpa adanya hambatan. Peran selaku Stabilisator Dinas Kelautan dan Perikanan dilakukan antara lain:

a. Menjaga Ketertiban Nelayan dalam Perlindungan Ikan Napoloen

Menjaga ketertiban nelayan dalam hal ini yakni Dinas Kelautan dan Perikanan untuk mengatur para nelayan waktu yang diperbolehkan untuk melakukan penangkapan ikan Napoleon. Misalnya, saat musim pemijahan ikan-ikan Napoleon dibiarkan dan diberi peluang untuk melakukan pemijahan secara alami tanpa langsung diambil di laut. Peraturan Menteri Kelautan dan Perikanan Nomor PER.03/MEN/2010 tentang Tata Cara Penetapan Status Perlindungan Jenis Ikan menjamin, keberadaan, ketersediaan dan kesinambungan jenis ikan tertentu. Status ikan napoleon bisa dikatakan telah memenuhi beberapa kriteria yang dicantumkan dalam perturan ini, seperti terancam punah, terjadinya penurunan jumlah individu dalam populasi ikan di alam secara drastis dan tingkat kemampuan reproduksi yang rendah.

Berdasarkan peraturan inilah, kemudian dikeluarkan keputusan menteri tentang status perlindungan jenis ikan napoloen yaitu Keputusan Menteri Kelautan dan Perikanan Republik Indonesia Nomor 37 Tahun 2013 tentang penetapan stastus perlindungan ikan napoleon (Cheilinus Undulates). Dijelaskan dalam peraturan tersebut bagian ketiga bahwa perlindungan terbatas untuk ukuran tertentu sebagaimana dimaksud yaitu:

1) Ikan napoleon berukuran dari 100 (seratus) gram sampai dengan 1000 (seribu) gram.

2) Ikan napoleon lebih dari 3000 (tiga ribu) gram.

Meskipun demikian, perdagangan secara terbatas masih diperbolehkan dengan penerapan sistem kuota yang membatasi jumlah ikan yang boleh diekspor per tahun dan pintu ekspor ke luar negeri, (Ronnysyam, 2016:117). Secara nasional aturan mengenai perlindungan ikan Napoleon telah diatur melalui Keputusan Menteri Kelautan dan Perikanan Nomor 37 Tahun 2013 tentang Penetapan Status Perlindungan Ikan Napoleon. Sementara, di Desa Air Sena sendiri, Dinas Kelautan dan Perikanan telah membuat kebijakan atau peraturan yang berupa surat kesepakatan bersama dengan para nelayan disana.I

Surat Kesepakatan Bersama Tentang Tata Cara Pengambilan/Penangkapan Benih Ikan Napoleon (Ketipas) Di Perairan Laut Kabupaten Kepulauan Anambas Tahun 2012 yang dibuat oleh Dinas Kelautan dan Perikanan untuk 
perlindungan ikan Napoleon yang telah di setujui oleh masing-masing desa yang dihadiri oleh, Camat, UPTD, Kepala Desa, Ketua Pokmaswas, BPD serta tokoh-tokoh masyrakat nelayan. Dalam Kesepakatan Bersama ini mengatur hal-hal berikut:

a) Pasal 1 Ukuran: Bahwa ukuran benih/bibit ikan napoleon yang dibolehkan untuk ditangkap ialah berukuran paling kecil atau minimal 0.5 inchi.

b) Pasal 2 Alat Tangkap: bahwa jenis alat tangkap yang diperbolehkan ialah jenis alat tangkap yang tidak merusak lingkungan ialah tangkul, jaring bagan, jarring kelambu untuk mengepung dan jaring tali urat.

c) Pasal 3 Cara Pengambilan/Penangkapan: Tidak mencabut krengkam ataupun merusak terumbu karang dan tidak menggunakan bius atau potas, tuba, bahanbahan cair, padat dan serbuk yang bisa merusak habitat ikan Napoleon.

d) Pasal 4 Waktu: penangkapan secara bersama di setiap daerah penangakapan di masing-masing desa dimulai tanggal 01 Januari s/d 30 Juni setiap tahunnya.

e) Pasal 5 Sanksi: sebagaimana dimaskud dalam pasal 1,2, 3 dan 4, sanksi yang ditetapkan, menyita alat tangkap dan diserahkan ke desa asal penggar, ikan hasil tangkap Napoleon di lepas ke laut, tidak bolehkan menangkap selama 1 tahun.

f) Pasal 6 Pengawasan: bahwa pengawasan terhadap kesepakatan ini akan dilakukan secara bersama-sama oleh seluruh anggota masyarakat di desa masing-masing dan akan dibantu oleh instansi terkait.

g) Pasal 7 Pelapor: Jika terjadi pelanggaran dalam kesepakatan ini maka setiap anggota masyarakat berkewajiban untuk melaporkan kepada RT, RW, Kepala Dusun, Kepala Desa, Ketua BPD, UPTD Dinas Kelautan dan Perikanan dan Ketua Nelayan di masingmasing desa.

h) Pasal 8 Penutup: Hal-hal yang belum diatur dalam surat kesepakatan bersama ini sepanjang mengenai pelaksaannya akan diatur lanjut oleh Kepala Desa masing-masing.

Namun, dalam implementasi di lapangan. Masih ada sebagian nelayan yang tidak mengetahui adanya pemberlakuan surat kesepakatan bersama tersebut. Ada juga nelayan yang mengetahui kesepakatan tersebut tetapi tidak mau mengikutinya dengan alasan apa yang ada dalam keputusan bersama tersebut berbeda dengan apa yang selama ini selalu dilakukan oleh nelayan Desa Air Sena dalam menangkap ikan Napoleon.

Musim puncak penangkapan ikan Napoleon terjadi pada bulan November dan Desember setiap tahunnya berdasarkan banyaknya jumlah anakan ikan Napoleon yang ditemukan di sekitar terumbu karang pada bulan tersebut. Pada musim puncak, jumlah anakan ikan Napoleon yang ditangkap para nelayan dapat mencapai antara 20 sampai dengan 30 ekor dalam satu trip penangkapan. Lamanya satu trip penangkapan berkisar antara 8 sampai dengan 12 jam, karena itu nelayan tidak mau mengikutinya aturan yang dibuat, aturan yang dibuat penangkapan dilakukan pada bulan januari sedangakan pada bulan tersebut menurut nelayan hanya sedikit yang bisa didapatkan oleh nelayan ikan Napoloen.

Permasalahan ikan Napoleon sendiri merupakan suatu tantangan yang perlu ditangani dengan bijak karena banyak penduduk Kabupaten Kepulauan Anambas khususnya di Desa Air Sena yang secara ekonomi bergantung kepada haiul tangkapan ikan Napoleon. Peraturan ini tidak dengan serta merta akan memberikan dampak positif yang diinginkan, meski disatu sisi regulasi dilakukan untuk menjamin konsistensi penerapan aturan, di sisi lain hal ini dapat menimbulkan konflik.

\section{b. Menjaga Kestabilan Ekonomi Nelayan Ikan Napoloen}

Sektor perikanan selain dapat berfungsi sebagai mata pencaharian masyarakat dan mendorong pertumbuhan ekonomi masyarakat juga dapat memanfaatkan sumberdaya alam kelautan, karena di Indonesia luas lautan mencapai $70 \%$ dari total keseluruhan. Peningkatan kualitas perikanan dalam hal ini merupakan tahap pengembangan masyarakat nelayan yang dilakukan oleh Dinas Kelautan dan Perikanan Kabupaten Kepulauan Anambas dalam menjaga kestabilan pembangunan ekonomi masyarakat nelayan.

Bantuan Dinas Kelautan dan Perikanan kepada masyarakat nelayan merupakan bentuk pengembangan yang diberikan pemerintah kepada masyarakat nelayan yang mana hal ini sangat membantu masyarakat nelayan Kabupaten Kepulauan Anambas khusunya desa Air Sena. Dinas Kelautan dan Perikanan memberikan bantuan kepada nelayan seperti tempat penampung ikan dan sarana lain penunjang pengembangan usaha agar dapat dipergunakan dengan sebaik-baiknya.

Selain itu Dinas Kelautan dan Perikanan membuat Kelompok Usaha Bersama kepada masyarakat nelayan, hasil tangkapan ikan kemudian dapat diolah membuat kerupuk, abon dan lain sebagainya. Agar meningkatkan pendapat dan 
mensejahterakan kehidupan nelayan. sehingga masyarakat nelayan tidak hanya bergantungan kepada pencarian ikan Napoloen. Usaha itu sangat membantu masyarakat nelayan untuk perekonomiannya. Sehingga pontensi sumber daya laut bisa dimanfaatkan nelayan selain menjual hasil tangkapan juga bisa mengelola hasil laut lainnya.

Tanggungjawab pemerintahan di daerah terutama Dinas Kelautan dan Perikanan Kepulauan Anambas dalam rangka memberdayakan dan meningkatkan kesejahteraan rakyat semakin kompleks, dimana selain bertanggungjawab memberikan pelayanan dan pembangunan, pemerintah daerah juga harus aktif untuk melaksanakan pemberdayaan masyarakat. Oleh sebab itu, pemberdayaan yang dilaksanakan perlu diarahkan dengan memperhatikan segala aspek kehidupan terutama perekonomian rakyat, terutama yang berada di daerah, meliputi wilayah kecamatan maupun pedesaan.

\section{Peran Selaku Inovator}

Dalam administrasi pembangunan, inovator yaitu orang yang mampu menemukan hal-hal yang baru, ide yang baru, dan sistem yang baru dalam proses pembangunan. Sebagai inovator, berarti Dinas Kelautan dan Perikanan secara keseluruhan bisa menjadi sumber-sumber ide baru terutama yang berhubungan dengan kegiatan pembangunan kelautan dan perikanan agar lebih efektif. Peran selaku Inovator Dinas Kelautan dan Perikanan dalam perlindungan ikan Napoloen bisa berupa tindakan yang dilakukan dalam hal:

\section{a. Membuat Satu Lokasi Khusus Perlindungan Ikan} Napoleon

Upaya perlindungan dan pemulihan ikan Napoloen di perairan Anambas merupakan langkah pengelolaan agar sumberdaya ikan Napoleon di perairan ini tetap terjaga. Ikan napoloen merupakan komoditas unggulan perairan Anambas khususnya bagi nelayan di Desa Air Sena dari kegiatan budidaya.

Kegiatan pemanfaatan ikan Napoleon sampai saat ini masih dilakukan oleh masyarakat nelayan Kabupaten Kepulauan Anambas khususnya di Desa Air Sena meskipun ikan Napoleon telah ditetapkan sebagai rawan punah, namun permintaan pasar terhadap ikan Napoleon hidup dari negara tetangga diantaranya Hongkong dan China semakin tinggi sehingga peningkatan pemanfaatan sumberdaya ikan Napoleon meningkat. Sehingga dalam perlindungan ikan Napoleon Dinas Kelautan dan Perikanan Kabupaten Kepulauan Anambas akan membuat satu lokasi khusus dimana dengan lokasi khusus tersebut melarang nelayan melakukan penangkapan terhadap ikan Napoleon.

Dengan adanya lokasi khusus ikan Napoleon bisa terlindungi dan juga pembudidaya dapat menjualnya. Lokasi khusus ini baru akan direncanakan, letak lokasi berada di daerah desa Batu Belah dimana jika dilihat lokasi tersebut terdapat pemijahan ikan Napoleon.

b. Alternatif Penerapan Budidaya Ikan Kerapu oleh Nelayan

Kemampuan sebagai inovator pembangunan Dinas Kelauatan dan Perikanan adalah kemampuan menterjemahkan program pembangunan daerah dengan bahasan yang sederhana serta menggugah keinginan dan mengikutsertaan masyarakat dalam pengelolaan bidang kelautan dan perikanan.

Dalam hal ini inovasi yang dilakukan oleh oleh Dinas Kelautan dan Perikanan bersama masyarakat Kabupaten Kepulauan Anambas khususnya desa Air Sena, tidak hanya bergantung pada pencarian ikan Napoleon. Dinas Kelautan dan Perikanan dapat membuat suatu program atau kebijakan yang dapat menunjang kehidupan nelayan ikan Napoleon. Selama dikeluarkan berbagai kebijakan dan peraturan mengenai perlindungan pada ikan Napoleon membuat ruang gerak nelayan yang menjual menjadi terbatas sehingga kehidupan perekonomian masyarakat nelayan menjadi berkurang.

Agar masyarakat nelayan tidak hanya bergantung pada penjualan pada ikan Napoleon dari Dinas Kelautan dan Perikanan memberi arahan agar masyarakat nelayan bisa membudidaya ikan lain yang mempunyai nilai ekonomi tinggi seperti ikan Kerapu dan lain sebagainya selain ikan Napoleon. Dinas Kelautan dan Perikanan membentuk kelompok nelayan, dengan adanya kelompok tersebut Dinas Kelautan dan Perikanan memberikan bantuan berupa benih ikan Kerapu agar dapat dibudidayakan dan tidak hanya bergantung pada ikan Napoleon. Benih ikan Kerapu yang diberikan berupa jenis menjual ikan Kerapu Cantik, Kerapu Bebek, dan sebaginnya.

Meskipun saat ini pembibitan ikan kerapu yang dibantu oleh Dinas Kelautan dan Perikanan masih berjalan dengan baik, tetapi masih ada juga nelayan di Desa Air Sena yang melakukan pencarian ikan Napoleon. Karena menurut mereka ikan Napoleon adalah ikan yang mahal atau memiliki nilai jual yang tinggi dibandingkan dengan jenis ikan lainnya. Sehingga masih ada juga nelayan di Desa Air Sena yang tetap mencari ikan Napoleon sebagai mata pencahariannya. 


\section{Peran Selaku Modernisator}

Peran selaku modernisator, Dinas Kelautan dan Perikanan diharapkan memiliki pola pemikiran yang maju dan tidak selalu berpatokan kepada pandangan lama. Dinas Kelautan dan Perikanan harus mampu mengubah pola pemikiran lama menjadi pola pemikiran modern untuk mencapai suatu tujuan yang akan dicita-citakan. Dinas Kelauatan dan Perikanan selaku modernisator harus dapat membuat perencanaan program pembangunan kelautan dan perikanan didaerahnya sesuai dengan kondisi yang ada.

Peran yang dilakukan Dinas Kelautan dan Perikanan sebagai modernisator dalam perlindungan ikan Napoleon demi tercapainya tujuan pembangunan Kelautan dan Perikanan. Peran selaku modernisator dapat berupa tindakan yang dilakukan antara lain:

a. Penguasaan Ilmu Pengetahuan dan Teknologi dalam Perlindungan Ikan Napoleon

Dinas Kelautan dan Perikanan belum memiliki cara maupun teknologi modern yang bisa diterapkan untuk membudidayakan ikan Napoleon, saat ini hanya teknik pembesaran secara konvensional yang dapat dilakukan oleh masyarakat nelayan disana. Dari Dinas Kelautan dan Perikanan mengupayakan perlindungan dan pelestariannya dengan cara melepaskan sejumlah bibit tertentu yang ditangkap kembali ke alam, dengan begitu ikan Napoleon yang sebagian dilepaskan akan berkembang biak secara alami.

Mayoritas masyarakat nelayan di Desa Air Sena mengatahui ikan Napoleon merupakan salah satu jenis ikan yang jumlahnya dibatasi untuk ditangkap. Namun pada kenyataanya para nelayan tetap melakukan penangkapan ikan Napoleon, para nelayan beranggapan bahwa ikan Napoleon yang ada di wilayah meraka jumlahnya masih sangat banyak sehingga belum masuk kategori punah.

Ada juga upaya-upaya yang dilakukan oleh nelayan untuk menjaga kelestarian ikan Napoleon di Desa Air Sena salah satunya adalah masyarakat nelayan Desa Air Sena masih menggunakan alat tangkap yang bersifat tradisional yang tidak merusak lingkungan laut dan habitat dari ikan Napoleon. Untuk budidaya ikan Napoleon, biasanya dipelihara di dalam keramba. Ada dua jenis keramba yang digunakan oleh para pembudidaya yaitu karamba tancap dan karamba jaring apung.

Kegiatan budidaya di Desa Air Sena Kepulauan Anambas, hanya dilakukan melalui pembesaran ikan Napoleon secara penuh yang dapat dilakukan yaitu, sampai ikan mencapai berat 6 sampai 8 ons. Ini berarti hanya budidaya ini yang layak dan bisa dilakukan agar pembudidaya bisa mendapatkan untung. Usaha budidaya ikan Napoleon di Desa Air Sena yang menjadi sumber mata pencaharian utama yang dilakukan oleh masyrakat nelayan Desa Air Sena hingga saat ini. Kegiatan budidaya pembesaran ikan Napoleon memberikan manfaat ekonomi bagi masyarakat setempat.

b. Menjadikan Budidaya Ikan Napoleon sebagai Salah Satu Objek Wisata

Luas laut Kabupaten Kepulauan Anambas \pm 46.664 .15$ km2, sehingga Kepulauan Anambas dijuluki sebagai negeri bahari dengan penduduknya yang berjumlah kurang lebih 41.388 jiwa. Proses budidaya ikan Napoleon yang dilakukan oleh nelayan di Desa Air Sena sudah menghasilkan lebih dari 100.000 ekor.

Budidaya ikan Napoleon yang dilakukan di Anambas, sangat potensial untuk dikembangkan sebagai salah satu lokasi tujuan wisata. Mengingat, Kabupaten Kepulauan Anambas memiliki luas wilayah laut dan pantai sebagai modal yang dapat digunakan untuk melakukan budidaya ikan Napoleon. Oleh karena itu, budidaya ikan Napoleon bisa menjadi salah satu tujuan wisata yang unik dibandingkan dengan daerah lainnya. Keunikan nama, bentuk serta harga ikan Napoleon yang cukup tinggi dapat menjadi daya tarik tersendiri.

Proses budidaya ikan Napoleon dilakukan dengan menempatkan ikan Napoelon pada sebuah wadah yang terbuat dari jaring ikan sebanyak dua lapis yang diletakkan di dasar laut, lalu ditegakkan dengan batang-batang kayu berdiameter kira-kira 15-20 sentimeter. Bentuknya menyerupai karamba jaring. Air yang digunakan adalah air langsung dari laut, karamba jaring itu berukuran lebih kurang 4 x 4 meter dengan kedalaman sekitar dua meter.

\section{Peran Selaku Pelopor}

Selaku pelopor, Pemerintah harus menjadi panutan (role model) bagi seluruh masyarakat. Sebagai pelopor berarti Dinas Kelautan dan Perikanan harus menjadi panutan bagi seluruh masyarakat. Ini berarti kepeloporan Dinas Kelautan dan Perikanan harus bersifat objektif untuk menunjang kelancaran pembangunan dibidang kelautan dan perikanan. Peran selaku pelopor dapat berupa tindakan yang dilakukan dalam hal:

\section{a. Upaya Dinas Kelautan dan Perikanan dalam Menyampaikan Aspirasi Masyarakat Nelayan}

Adanya Keputusan Menteri Kelautan dan Perikanan Nomor 37 Tahun 2013 tentang tentang tentang Penetapan 
Status Perlindungan Terbatas Ikan Napoleon yang juga diterpakan di Kabupaten Kepulauan Anambas membuat masyarakat Anambas khususnya di Air Sena mengalami keresahan, karena banyak masyarakat Air Sena secara ekonomi bergantung pada penjualan ikan Napoloen. Dinas Kelauatan dan Perikanan berupaya untuk mendengarkan keluhan dan keresahan yang dirasakan oleh masyarakat nelasyan berkaitan dengan peraturan ini.

Bagi masyarakat di Kabupaten Kepulauan Anambas, Keputusan Menteri ini dirasa kurang tepat untuk dilaksanakan. Di Anambas, ikan Napoleon masih sangat berlimpah dan belum dikatakan punah. Penangkapan ikan Napoleon yang dilakukan oleh masyarakat nelayan di Kepulauan Anambas terutama di Desa Air Sena masih menggunakan peralatan yang tidak merusak habitat ikan Napoleon dan ramah terhadap lingkungan laut. Selain itu, banyak nelayan selain menangkap ikan Napoleon tetapi juga memiliki kerambah untuk melakukan budidaya ikan Napoleon dan mencegah dari kepunanahan. Peran selaku pelopor telah dijalan oleh Dinas Kelautan dan Perikanan Kabupaten Kepulauan Anambas dengan meminta kepada Pemerintah Pusat agar penjualan ikan Napoloen bisa dijual seperti dulu lagi.

Dinas Kelautan dan Perikanan Kabupaten Kepulauan Anambas telah meminta kepada Pemerintah untuk melakukan peninjauan kembali terhadap Keputusan Menteri tersebut. Ada beberapa hal yang disampaikan oleh Dinas Kelautan dan Perikanan kabupaten Kepulauan Anambas: 1) Dinas Keluatan dan Perikanan meminta kepada Pemerintah Pusat untuk memperjuangkan agar bagaimana caranya agar ikan Napoleon yang ada di Anambas ini sebagai hasil ikan budidaya karena di Anambas ikan Napoleon yang ditangkap berukuran kecil kemudian dipelihara sampai 5 tahun dan baru diperdagangkan; 2) Dinas Kelautan dan Perikanan meminta agar perdagangan ikan Napoleon dapat dilakukan melalui transportasi laut sehingga bisa diekspor seperti sebelumnya.

Pada Keputusan Menteri Kelautan dan Perikanan Nomor 37 Tahun 2013 tentang tentang Penetapan Status Perlindungan Terbatas Ikan Napoleon terdapat beberapa hal yang tidak sesuai dengan kenyataan di masyarakat. Pada Keputusan Menteri tersebut dinyatakan bahwa ukuran ikan Napoleon dibawah $1 \mathrm{~kg}$ tidak boleh ditangkap dan diperdagangkan, sementara pasar ekspor menginginkan ukuran dibawah $1 \mathrm{~kg}$ (6-8 ons) sehingga tidak ketemu antara permintaan pasar dengan Keputusan Menteri tersebut. Akibatnya yang dirugikan adalah masyarakat nelayan. Di Billy Jenawi satu sisi berkaitan dengan pemenuhan ekonomi tetapi disisi lainnya berbenturan dengan peraturan.

b. Meningkatkan Kesadaran Masyarakat Nelayan dalam Perlindungan Ikan Napoleon

Sebuah kebijakan yang dibuat perlu mendapat respon positif dari masyarakat, karena langsung ataupun tidak langsung sebuah kebijakan pasti akan berdampak bagi masyarakat itu sendiri. Sama halnya seperti Keputusan Menteri Kelautan dan Perikanan Nomor 37 Tahun 2013 tentang tentang Penetapan Status Perlindungan Terbatas Ikan Napoleon. Dinas Kelautan dan Perikanan Kabupaten Kepulauan Anambas melaksanakan tugasnya dengan meningkatkan kesadaran masyarakat nelayan dengan memberikan sosialisasi tentang perlindungan ikan Napoleon. Sosialisasi merupakan salah satu tahapan yang penting dalam proses implementasi sebuah kebijakan.

Pada Keputusan Menteri Kelautan dan Perikanan Nomor 37 Tahun 2013 tentang Penetapan Status Perlindungan Terbatas Ikan Napoleon masayarakat nelayan berperan penting dalam melaksanakan kebijakan tersebut. Oleh karena itu, perlu adanya sosialiasi yang dilakukan untuk memberikan pemahaman tentang kebijakan yang diberlakukan dan apa saja hal-hal yang terdapat dalam kebijakan itu sendiri. Dalam kebijakan ini, masyarakat nelayan merupakan sasaran yang akan melaksanakan kebijakan tersebut.

Dinas Kelautan dan Perikanan Kabupaten Kepulauan Anambas melakukan sosialisasi sebulan sekali masayarakat nelayan dan ketua-ketua kelompok nelayan. Sosialisasi tersebut dilakukan pada hari yang berdasarkan kesepakatan bersama antara Dinas Kelautan dan Perikanan dengan masyarakat nelayan. Selain melalui sosialisasi melaui pertemuan langsung dengan masyarakat nelayan, sosialisasi juga dilakukan melalui surat himbauan.

Selama ini sosialisasi yang dilakukan hanya bertumpu pada sosialisasi secara langsung dan melalui surat himbauan. Sehingga pesan yang ingin disampaikan melalui kebijakan ini tidak tersampaikan dengan baik. Sosialisasi yang dilakukan kepada ketua-ketua nelayan juga tidak ditindaklanjuti dengan baik dengan menyampaikan kembali kepada nelayan-nelayan yang ada pada kelompok mereka.

\section{Peran Selaku Pelaksana}

Peran pemerintah sebagai stabilisator, inovator, modernisator, pelopor, dan pelaksana sendiri, pembangunan nasional harus diwujudkan melalui pelaksanaan fungsi seluruh elemen pemerintah dengan ideal atau sesuai dengan aturan yang 
berlaku, sehingga terjadi keseimbangan dan gerak yang dinamis dalam roda pemerintahan yang baik. Peran yang dilakukan Dinas Kelautan dan Perikanan sebagai pelaksanaan sendiri berbagai kegiatan pembangunan Kelautan dan Perikanan ialah:

\section{a. Pengawasan terhadap Penangkapan Ikan Napoloen}

Pengawasan merupakan bagian terpenting dalam melaksanakan sebuah aktivitas atau kegiatan, sehingga dalam seluruh aspek kehidupan sesungguhnya kita diawasi dan kita melakukan pengawasan terhadap apa yang ada dilingkungan kita sebagai salah satu cara untuk melindungi diri dan menilai dari apa yang diri sendiri kerjakan maupun orang lain kerjakan. Peran yang dilakukan oleh Dinas Kelautan dan Perikanan Kabupaten Kepulauan Anambas sebagai pelaksana dalam berbagai kegiatan pembangunan khususnya dibidang Kelautan dan Perikanan berkaitan dengan Keputusan Menteri Kelautan dan Perikanan Nomor 37 Tahun 2013 tentang Penetapan Status Perlindungan Terbatas Ikan Napoleon yaitu melakukan pengawasan dalam pelaksanaan.

Dinas kelautan dan Perikanan Kabupaten Kepulauan Anambas merupakan instansi pemerintah yang ditunjuk untuk melaksanakan fungsi pengawasan terhadap sumber daya kelautan dan perikanan di tingkat kabupaten. Dengan adanya peraturan tentang penetapan status perlindungan terbatas terhadap ikan Napoleon maka menjadi tanggungjawab Dinas Kelautan dan Perikanan sebagai perpanjangan tangan pemerintah pusat dengan melakukan pengawasan dengan menjaga dan melindungi habitat ikan Napoleon tersebut.

Dinas Kelautan dan Perikanan Kabupaten Kepulauan Anambas dalam melakukan pengawasan melibatkan masyarakat yaitu dengan dibentuknya Kelompok Masyarakat Pengawas (POKMASWAS). Intensitas pengawasan ditingkatkan bila ada laporan dari masyarakat, misalnya adanya kapal yang masuk ke wilayah laut Kabupaten Kepulauan Anambas yang membawa pukat mayang (alat tangkap yang dilarang) dan juga adanya laporan pengeboman ikan.

Kelompok Masyarakat Pengawas (POKMASWAS) yang dibentuk oleh Dinas Kelautan dan Perikanan bertugas sebagai perwakilan pemerintah dalam melakukan pengawasan di lapangan. Aduan-aduan dari masyarakat yang berkaitan dengan permasalahan kelautan dan perikanan disampaikan kepada POKMASWAS untuk ditindaklanjuti. Tetapi apabila permasalahan tersebut tidak mampu diatasi maka diserhkan kepada UPTD yang ada pada masingmasing daerah hingga ke Dinas Kelautan dan Perikanan.

30 Billy Jenawi

\section{SIMPULAN}

Peran Dinas Kelautan dan Perikanan Kabupaten Kepulauan Anambas dalam perlindungan ikan Napoleon dilihat dari dimensi:

1.Stabilisator; peran Dinas Kelautan dan Perikanan sebagai stabilisator dilakukan dengan menjaga ketertiban nelayan pada penangkapan ikan Napoleon dengan membuat kebijakan dalam bentuk surat keputusan bersama antara Dinas Kelautan dan Perikanan dengan para nelayan, namun sayang kesadaran nelayan terhadap perlindungan ikan Napoleon masih rendah. Selain itu, untuk menjaga stabilitas ekonomi nelayan akibat dari Keputusan Menteri Kelautan dan Perikanan Nomor 37 Tahun 2013 tentang Penetapan Status Perlindungan Terbatas Ikan Napoleon, Dinas Kelautan dan Perikanan juga membantu dalam pembentukan kelompok usaha bersama yang mengolah hasil perikanan nelayan untuk membentu perekonomian meraka.

2.Inovator; Dinas Kelautan dan Perikanan membuat satu lokasi khusus yang dijadikan sebagai tempat perlindungan ikan Napoleon. Selain itu, Dinas Kelautan dan Perikanan juga menerapkan budidaya ikan Kerapu kepada nelayan dengan memberikan benih ikan tersebut untuk dapat dibudidaya dan menjadi salah satu sumber pendapatan sehingga tidak hanya bergantung pada hasil tangkap ikan Napoleon.

3.Modernisator; pada dimensi ini Dinas Kelutan dan Perikanan belum mampu menggunakan teknologi yang lebih modern untuk melakukan perlindungan dan pembudidayaan ikan Napoleon, sehingga masih dilakukan dengan caracara tradisional. Namun, Dinas Kelautan dan Perikanan ikan Napoleon sebagai salah satu objek wisata karena Kabupaten Kepulauan Anambas merupakan salah satu daerah yang banyak melakukan budidaya ikan Napoleon.

4.Pelopor; Dinas Kelautan dan Perikanan telah berupaya untuk menyampaikan aspirasi dan sikap masyarakat terhadap Keputusan Menteri Kelautan dan Perikanan Nomor 37 Tahun 2013 tentang Penetapan Status Perlindungan Terbatas Ikan Napoleon. Dinas Kelautan dan Perikanan juga melakukan sosialisasi dan himbauan untuk meningkatkan kesadaran masyarakat untuk melindungi ikan Napoleon.

5.Pelaksana; peran Dinas Kelautan dan Perikanan sebagai pelaksana dilakukan dengan mengawasi segala kegiatan yang berkaitan dengan Keputusan Menteri Kelautan dan Perikanan Nomor 37 Tahun 2013 tentang Penetapan Status Perlindungan Terbatas Ikan Napoleon. Pengawasan juga 
melibatkan masyarakat dengan dibentuknya Kelompok

Masyarakat Pengawas (POKMASWAS).

\section{DAFTAR PUSTAKA}

Ali, Hasyimi. A. 2002. Organisasi dan Manajemen. Jakarta: Bumi Aksara.

Dwi, Narwoko, dan Suyanto, Bagong. Sosiologi Teks Pengantar dan Terapan. Jakarta: Kencana. 2011.

Edrus, Isa Nagib, Sasanti R. Suharti, Dirhamsyah, Sarmintohadi, dan Aris Wibowo. 2012. Pedoman Survei Populasi Ikan Napoleon (Cheilinus Undulatus Rüppell 1835). Jakarta: Direktorat Konservasi Kawasan dan Jenis Ikan Direktorat Jenderal Kelautan, Pesisir, dan Pulau-Pulau Kecil Kementerian Kelautan dan Perikanan.

Hardjito, Didiet. 2001. Teori Organisasi dan Teknik Pengorganisasian. Jakarta: Raja Grafindo Persada.

Pasolong, Harbani. 2014. Teori Administrasi Publik. Bandung: Alfabeta.

Riyadi. 2002. Perencanaan Daerah Strategi Mengendalikan Potensi dalam Mewujudkan Otonomi Daerah. Jakarta: Gramedia.

Siagian, Sondang P. 2000. Administrasi Pembangunan. Jakarta: PT Bumi Aksara.

Sudarhono, Edy. 2016. Teori Peran. Jakarta: Gramedia Pustaka Utama.

Sumaryadi, Nyoman. 2010. Sosiologi Pemerintahan. Bogor: Ghalia Indonesia.

Syafri, Wirman. 2012. Studi tentang Administrasi Publik. Jakarta: Erlangga.

Thoha, Miftah. 2009. Kepemimpinan dan Manajemen. Jakarta: PT Raja Grafindo Persada.

Jurnal :

Syam, Amran Ronny, Mujiyanto dan Masayu Rahmia Anwar Putri. 2016. Dugaan Daerah Pemijahan Ikan Napoleon (Cheilinus Undulatus,Ruppell, 1835) di Sekitar Perairan Kepulauan Anambas. Jurnal Penelitian Perikanan Indonesia, Volume 22, Nomor 3.

Asiati, Devi dan Nawawi. 2016. Kemitraan Di Sektor Perikanan Tangkap: Strategi Untuk Kelangsungan Usaha Dan Pekerjaan. Jurnal Kependudukan Indonesia,Vol. 11 No. 2.

Ismail, M. 2013. Implementasi Program Pelestarian Sumberdaya Kelautan dan Perikanan Di Kabupaten Situbondo", Jurnal Review Politik, Volume 03, Nomor 02.

Dokumen :

Keputusan Menteri Kelautan dan Perikanan Nomor 37 Tahun 2013 tentang tentang Penetapan Status Perlindungan Terbatas Ikan Napoleon (Cheilinus Undulatus).

Peraturan Menteri Kelautan dan Perikanan Nomor PER.03/MEN/2010 tentang Tata Cara Penetapan Status Perlindungan Jenis Ikan.

Peraturan Daerah Kabupaten Kepulauan Anambas Nomor 6 Tahun 2011 Pasal 77 Dinas Kelautan dan Perikanan

Website :

http://bpsplpadang.kkp.go.id/status-perlindungan-napoleon 